\title{
Gibalna/športna (ne)aktivnost vzgojiteljic in njihova kompetentnost za razvoj gibanja predšolskih otrok v prvem starostnem obdobju
}

\author{
Matej Plevnik \\ Univerza na Primorskem \\ matej.plevnik@fvz.upr.si \\ Tanja Peternelj \\ Univerza na Primorskem \\ peternelj.tanja@gmail.com
}

\begin{abstract}
Potreba po gibanju je otrokova primarna potreba. Zato ima razvoj gibanja, kot enega od področij dejavnosti v vrtcu, še poseben pomen. Otrok je v zgodnjem otroštvu izredno dojemljiv za impulze okolja, vpliv v tem obdobju pridobljenih gibalnih izkušenj je za njegov nadaljnji razvoj izredno pomemben. Vrtec je poleg staršev v obdobju otroštva izredno pomembno okolje, saj otroci v njem preživijo večino svojega dneva. Otroci naj bi bili v okolju vrtca deležni mnogoterih gibalnih izkušenj, kar pa je povezano z ustreznim načrtovanjem, organiziranjem, izvajanjem in vrednotenjem izvedbe gibalnih/športnih aktivnosti s strani vzgojiteljice, na kar ima vpliv tudi njena kompetentnost za vodenje omenjenih vsebin. V študiji je sodelovalo 65 vzgojiteljic, ki poučujejo predšolske otroke $v$ prvem starostnem obdobju. Zanimala nas je razvitost njihovih kompetenc za razvoj vsebin gibanja, tudi v povezavi z njihovo lastno redno gibalno/športno aktivnostjo. Ugotovili smo, da gibalno/športno aktivnejše vzgojiteljice svoje kompetence za razvoj gibanja predšolskih otrok ocenjujejo višje. Ključne besede: razvoj, gibalna/športna aktivnost, kompetentnost, otrok, okolje
\end{abstract}

\section{Uvod}

Posamezna področja razvoja otroka so še posebej v predšolskem obdobju izrazito povezana in prepletena. Razvoj telesnega, gibalnega, senzornega, spoznavnega, čustvenega ali socialnega področja ima hkraten vpliv tudi na druga omenjena področja razvoja. $\vee$ predšolskem obdobju je pomemben cilj programov vzgoje in izobraževanja, v katere je otrok vključen, tudi izpostavljenost otroka bogatemu izkušenjskemu okolju, v katerem bo lahko razvijal svoje potenciale in si pridobival pestro ter široko paleto raznovrstnih izkušenj na vseh področjih razvoja, ki jih bo v prihodnosti bogatil in nadgrajeval (Gallahue, Ozmun in Goodway 2012, 186; Pišot in Jelovčan 2012, 28). Okolje otroka 
v predšolskem obdobju, vsaj v času vključenosti v redne programe vzgoje in izobraževanja, lahko delimo na vsaj dva pomembna vidika. Prvi je vidik fizičnega okolja, v katerega je vključen otrok. Tega predstavlja vrtec sam kot objekt, s tem povezana pa umestitev objekta $v$ širši prostor (npr. bližina narave, velikost zunanjih površin ...), značilnosti samega objekta (svetlost prostorov, velikost igralnic/učilnic, možnost izhoda na teraso ...), opremljenost objekta z igrali, s pripomočki in z drugo opremo ter druge značilnosti, vezane na vrtec kot objekt. Drugi, za razvoj predšolskega otroka pomembnejši, pa je vidik socialnega okolja. Tega predstavljajo drugi otroci, vključeni v oddelek, in vzgojitelj/-ica predšolskih otrok ter pomočnik/pomočnica vzgojitelja (ter drugi vključeni v oddelek), ki delo v oddelku načrtujeta, organizirata, izvajata in vrednotita. Kompetentnost vzgojiteljice za razvoj posameznih področij razvoja otroka v predšolskem obdobju je tesno povezana z vsebino in kvaliteto izvedenih aktivnosti.

Družbene, politične in gospodarske razmere družbe znanja so danes turbulentne in se odražajo tudi v vzgojno-izobraževalnem prostoru. Zato je pomembno, da se še posebej vzgojitelji in učitelji, ki delajo $z$ otroki v najranljivejših in najdločilnejših razvojnih obdobjih otroštva, zavedajo pomena vseživljenjskega učenja, ki temelji na poglabljanju in razvijanju ključnih kompetenc, na podlagi katerih načrtujejo, izvajajo in usmerjajo dejavnosti otrok $v$ predšolskem obdobju. Pouk $v$ družbi znanja se spreminja in $z$ njim vloga učitelja, ki ni več le prenašalec znanja, temveč moderator, animator, organizator spodbudnega učnega okolja, mentor in spodbujevalec samostojnega učenja (Retar in Lepičnik Vodopivec 2017, 2). Dokument o ustvarjalnih in inovativnih učnih okoljih med možnosti, s katerimi vzgojno-izobraževalne ustanove bogatijo obstoječe pristope poučevanja in vzgoje, umešča raznolikost in prepletanje pedagoških prijemov, ki učence pritegnejo k udejstvovanju in uresničujejo prilagajanje posamezniku, kar se nanaša tudi na krepitev skupinskega dela ob hkratni individualizaciji (Organisation for Economic CoOperation and Development 2013, 14). Prilagajanje družbenim razmeram in smernicam različnih organizacij je odločujoče povezano $z$ vsaj tremi procesi, v katere je vključen vzgojitelj, to so učenje in motiviranost, kompetentnost za načrtovanje ter organiziranje, izvajanje in vrednotenje vsebine $v$ okviru programov predšolske vzgoje. Učenje UNESCO (2011) opredeljuje kot vsako spremembo v vedenju, informiranosti, znanju, razumevanju, stališčih, spretnostih ali zmožnostih, ki je trajna in je ne moremo pripisati fizični rasti ali razvoju podedovanih vedenjskih vzorcev (Maretič Požarnik 2012, 10). Motivacija povzroča in usmerja delovanje posameznika in obsega vsa gibala vedenja: potrebe, nagone, motive, želje, cilje, vrednote, ideale, interese in voljo 
(Kohont 2005, 36). Kompetentnost Retar, Plevnik in Kolar $(2013,5)$ opisujejo kot zmožnost uporabe znanja, spretnosti, izkušenj, veščin, odnosov, osebnostnih lastnosti in motivacije, da posameznik na sebi lasten način uspešno opravi pričakovano delo. Rezultat vzgojiteljeve kompetentnosti na določenem področju so torej načini načrtovanja, organizacije, izvedbe in vrednotenja vsebin predšolske vzgoje, $v$ katero je vključen otrok. Zato je zavedanje svoje kompetentnosti, ki vključuje tako prepoznavo strokovno močnih kot šibkejših področij, izredno pomembno za strokovno nadgrajevanje in bogatitev kompetenc vzgojitelja v procesu vseživljenjskega razvoja in učenja.

Gibalna/športna aktivnost ima v razvoju otroka izredno pomemben prispevek (Malina, Bouchard in Bar-Or 2004, 480; Weiler idr. 2013). Za njegov normalen razvoj in oblikovanje zrele osebnosti predstavlja nenadomestljiv vir izkušenj. Jasne smernice in priporočila glede količine in intenzivnosti gibalnih/športnih aktivnosti predšolskih otrok v prvem starostnem obdobju ne obstajajo, zgolj vsebinska priporočila (Timmons, Naylor in Pfeiffer 2007). Mednarodna in po njih povzeta nacionalna poročila o priporočljivi količini in intenzivnosti gibalne/športne aktivnosti se za otroke začnejo s petimi leti starosti (World Health Organization 2010). T. Volmut, P. Dolenc in Šimunič (2010, 25-26) to aktivnost opisujejo kot kompleksen proces, s tem povezano pa je tudi njeno merjenje in spremljanje. Narava gibalnih/športnih aktivnosti mlajših otrok se v marsičem razlikuje od gibalnih/športnih aktivnosti, ki so značilna za druge starostne skupine. Gibalna/športna aktivnost predšolskih otrok $v$ prvem starostnem obdobju je usmerjenja predvsem $v$ učenje komunikacije $z$ okoljem z usvajanjem lokomotornega gibanja (naravnih oblik gibanja), ki omogoča gibanje po prostoru, ter z izvedbo spretnostnih gibalnih veščin, ki omogočajo samostojno opravljanje nalog (npr. hranjenje z žlico, listanje knjig ...). V vsebino gibalnih/športnih aktivnosti so lahko vključene tudi nekatere lažje veščine in elementi posameznih športov, v kolikor so ustrezno osmišljeni. Obdobje prvega starostnega obdobja predšolskega otroka je obdobje razvoja temeljnih gibalnih vzorcev in spretnosti, med katere so vključene tudi nekatere športne veščine. Zato je področje gibanja $\checkmark$ predšolskem obdobju pogosto vsebinsko opredeljeno tudi kot področje gibalnih/športnih aktivnosti. Gibalne izkušnje predšolskega otroka ob zaključku prvega starostnega obdobja predstavljajo temelj prehoda v obdobje zgodnjega otroštva, ki je odločilno za razvoj kvalitete elementarnih gibalnih vzorcev in struktur (Plevnik in Pišot 2016, 31). Če otrok ne usvoji ustreznih gibalnih vzorcev, obstaja velika verjetnost, da bo imel v nadaljnjem gibalnem razvoju težave (Gallahue, Ozmun in Goodway 2012). Cilji za področje dejavnosti gibanja, ki so opredeljeni v Kurikulumu za vrtce (Ministrstvo za šolstvo 
in šport 1999), za otroke v prvem starostnem obdobju predvidevajo predvsem mnogotero in raznovrstno izpostavljenost različnim dražljajem okolja in nalog, ki spodbujajo pridobivanje bogatih gibalnih izkušenj in opravljanje različnih gibalnih izzivov $z$ namenom razvoja zavedanja lastnega telesa $v$ prostoru in doživljanja pozitivnih občutkov $v$ gibanju ter usvajanje najrazličnejših osnovnih gibalnih struktur (Videmšek in Pišot 2007, 112; Lemos, Avigo in Barela 2012).

Otrok je v zgodnjem otroštvu izredno dojemljiv za dražljaje okolja, vpliv gibalnih izkušenj je $v$ tem obdobju največji. Poznavanje osnovnih zakonitosti rasti in razvoja ter razvojnih značilnosti otrok je predpogoj za smiselno načrtovanje dela in izbiro primernih vsebin gibalnih/športnih aktivnosti. Vzgojitelj mora poznati biološke dejavnike razvoja otroka, teorijo gibalne/športne vzgoje in pedagoškega dela. Poznati mora tudi najrazličnejše otrokove lastnosti in sposobnosti, da proces usvajanja gibalnih vsebin primerno zastavi in ga po potrebi tudi individualno prilagodi (Pišot in Jelovčan 2012, 7). Tu pa prihaja $v$ ospredje vzgojiteljeva kompetentnost za načrtovanje, organiziranje, izvajanje in vrednotenje vsebin gibalnih/športnih aktivnosti za otroke v predšolskem obdobju.

\section{Metode}

\section{Postopek zbiranja podatkov}

Za namen izvedbe študije smo oblikovali vprašalnik, ki smo ga vnesli v portal 1ka.si. Povezavo do vprašalnika smo poslali na več skupin, $v$ katere se združujejo vzgojiteljice predšolskih otrok na portalu facebook.si. Povezava je bila dostopna med 11. marcem in 1. junijem 2014. Vprašanja so se nanašala na več vsebinsko zaokroženih sklopov, in sicer: (i) osebne značilnosti vzgojiteljice (spol, starost, delovno mesto, delovna doba, delo s starostno skupino, zaposlitveni status, formalna izobrazba, kraj dela) (ii) značilnosti gibalnih navad vzgojiteljice (odnos do gibalne/športne aktivnosti, zgodovina gibalnega/športnega udejstvovanja), (iii) značilnosti vrtca (velikost vrtca, mnenje o opremljenosti z ustrezno infrastrukturo), (iv) kompetence za izvajanje različnih področij vsebin in (v) kompetence za izvajanje gibalne/športne aktivnosti.

Oceno kompetentnosti so preiskovanke ocenjevale na lestvici od 1 (izredno slaba ocena kompetentnosti) do 6 (odlično razvita kompetenca). Dosegli smo 503 klike na povezavo, pri čemer pa je bilo za nadaljnjo analizo ustrezno izpolnjenih 167 vprašalnikov. Vprašalnik je ustrezno izpolnilo 39 \% vzgojiteljic $(N=65)$, ki v vrtcu delajo $z$ otroki prve starostne skupine ter $61 \%$ vzgojiteljic $(N=102)$, ki v vrtcu delajo $z$ otroki druge starostne skupine. 


\section{Vzorec}

V nadaljnjo analizo smo skladno s cilji znanstvenega sestanka vključili odgovore vzgojiteljic, ki so v času izpolnjevanja vprašalnika v vrtcu delale $z$ otroki prve starostne skupine. Podvzorec preiskovancev, ki smo ga tako vključili v analize za potrebe prispevka, je predstavljal 65 enot.

Preiskovanci so bili v 64 primerih ženskega spola ${ }^{1}$ ter 1 primeru moškega spola, njihova povprečna starost je bila 37,1 $\pm 10,7$ let. Značilnosti njihovega zaposlitvenega statusa so bile naslednje: $80 \%$ preiskovank je imelo pogodbo o zaposlitvi za nedoločen čas, $18,5 \%$ preiskovank pogodbo za določen čas, $1,5 \%$ preiskovank pa jo bilo v delo vključenih kot pripravnice. $V$ povprečju so bile zaposlene 13,1 $\pm 12,02$ let (najmanj 1, največ 36 ).

Glede zgodovine ukvarjanja z gibalno/športno aktivnostjo je 52,3\% preiskovank navedlo, da so se $v$ preteklosti aktivno ukvarjale s športom (pomeni, da so bile vključene $v$ reden proces športne vadbe), medtem ko $47,7 \%$ preiskovank nima zgodovine rednega ukvarjanja s športom. Glede trenutnega statusa ukvarjanja z gibalno/športno aktivnostjo (kar pomeni redno izvajanje gibalne/športne aktivnosti, vsaj 2-krat tedensko) je 64,4\% preiskovank odgovorilo, da so redno gibalno/športno aktivne, in $35,6 \%$, da niso.

\section{Obdelava podatkov}

Podatke smo analizirali $z$ računalniškim programom za statistične analize SPSS 23.0, in sicer z metodami opisne statistike. Rezultati so prikazani kot aritmetična sredina \pm standardni odklon ( $\mathrm{AS} \pm \mathrm{SO}$ ). Po testiranju predpostavk statističnih testov smo statistično značilnost razlik $v$ oceni kompetentnosti med skupinama redno gibalno/športno aktivnih in neaktivnih vzgojiteljic izračunali z neparametričnim Mann-Whitneyevim U-testom. Stopnjo tveganja smo določili pri $p<0.05$.

\section{Rezultati in razprava}

Preiskovanke so navedle, da so zaposlene $v$ vrtcu, v katerega je po njihovi oceni vključenih $247,2 \pm 237,11$ otrok (najmanj 19, največ 750 ). Glede opremljenosti vrtca z opremo za izvajanje gibalnih/športnih aktivnosti $20 \%$ preiskovank ocenjuje, da je opremljenost vrtca odlična (imajo na voljo več opreme, kot jo običajno uporabljajo); $58,5 \%$, da je zadovoljiva (imajo na voljo toliko opreme, kot jo redno tudi uporabljajo), ter 21,5\% preiskovank, da je opremljenost slaba (opreme in pripomočkov za delo jim primanjkuje).

\footnotetext{
'Zaradi prevladujočega števila preiskovancev ženskega spola bomo v nadaljevanju za oba spola uporabljali žensko slovnično obliko.
} 
Preglednica 1 Ocena kompetentnosti za izvajanje vsebin področij dejavnosti v predšolski vzgoji

\begin{tabular}{lrr}
\hline Področje dejavnosti & AS \pm SO & $p$ \\
\hline Gibanje & $4,9 \pm 0,85$ & $U=196, p=0,022$ \\
Umetnost & $4,9 \pm 0,84$ & \\
Jezik & $4,9 \pm 0,82$ & \\
Družba & $4,8 \pm 0,81$ & \\
Narava & $4,8 \pm 0,82$ & \\
Matematika & $4,6 \pm 0,74$ & \\
\hline
\end{tabular}

Opombe AS - aritmetična sredina, SO - standardni odklon, $p$ - statistično značilna razlika v oceni kompetentnosti med gibalno/športno aktivnimi in neaktivnimi vzgojiteljicami.

Z vidika izvajanja posameznih področij dejavnosti smo vzgojiteljice najprej povprašali o njihovi oceni kompetentnosti za izvajanje posamezne vsebine (preglednica 1).

Skupina gibalno/športno (G/Š) aktivnih vzgojiteljic statistično značilno višje ocenjuje svojo kompetentnost za izvajanje vsebin področja gibanja (G/Š aktivne $5,12 \pm 0,69 ; G / S ̌$ neaktivne $4,5 \pm 0,99 ; U=196, p=0,022)$. Ocena kompetentnosti za izvajanje drugih področij se med omenjenima skupinama statistično značilno ne razlikuje. Vzgojiteljice, ki delajo z otroki v prvem starostnem obdobju, najvišje ocenjujejo svojo kompetentnost za izvajanje dejavnosti s področij gibanja, umetnosti in jezika, slabše pa ocenjujejo kompetence za izvajanje vsebin matematike.

Skupina gibalno/športno aktivnih vzgojiteljic statistično značilno višje ocenjuje naslednje kompetence izvajanja gibalnih/športnih aktivnosti z vidika načrtovanja (preglednica 2): znam pripraviti letni program gibalnih/ športnih aktivnosti (G/Š aktivne 4,61 \pm 0,83; G/Š neaktivne $3,78 \pm 1,11 ; U=$ 173; $p=0,010)$, znam prepoznati otroke $s$ posebnostmi $v$ gibalnem razvoju in prilagajati delo njihovim posebnostim (G/Š aktivne $4,71 \pm 1,0$; $G / S ̌$ neaktivne $4,11 \pm 1,0 ; U=207 ; p=0,048)$, znam načrtovati program gibalnih/športnih aktivnosti z organizacijskega vidika (G/Š aktivne $4,82 \pm 0,83 ; \mathrm{G} / \mathrm{S}$ neaktivne 4,11 $\pm 1,02 ; U=187,5 ; p=0,016$ ), znam načrtovati program gibalnih/športnih aktivnosti s količinskega vidika (G/Š aktivne 4,82 $\pm 0,80$; G/Š neaktivne 4,06 $\pm 1,0$; $U=184,5 ; p=0,013)$, znam načrtovati program gibalnih/športnih aktivnosti z didaktičnega vidika (G/Š aktivne 5,00 $\pm 0,78 ; \mathrm{G} / S ̌$ neaktivne 4,22 $\pm 0,94 ; U=$ $178 ; p=0,009$ ) ter znam načrtovati svoj strokovni razvoj in vseživljenjsko uče-

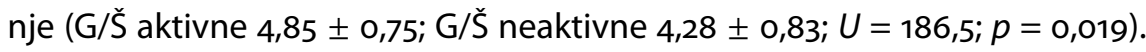
Vzgojiteljice, ki delajo z otroki v prvem starostnem obdobju, pri izvajanju gibalnih/športnih aktivnosti v vrtcu z vidika načrtovanja najvišje ocenjujejo 
Preglednica 2 Ocena kompetentnosti za izvajanje gibalnih/športnih aktivnosti v vrtcu z vidika načrtovanja

\begin{tabular}{lrr}
\hline Trditev & $\mathrm{AS} \pm \mathrm{SO}$ & $p$ \\
\hline $\begin{array}{l}\text { Znam oblikovati učno pripravo za uro gibalnih/športnih } \\
\text { aktivnosti }\end{array}$ & $5,2 \pm 0,87$ & \\
$\begin{array}{l}\text { Znam načrtovati program gibalnih/športnih aktivnosti z } \\
\text { didaktičnega vidika }\end{array}$ & $4,7 \pm 0,91$ & $U=178 ; p=0,009$ \\
$\begin{array}{l}\text { Znam načrtovati svoj strokovni razvoj in vseživljenjsko } \\
\text { učenje }\end{array}$ & $4,6 \pm 0,82$ & $U=186,5 ; p=0,019$ \\
$\begin{array}{l}\text { Znam načrtovati program gibalnih/športnih aktivnosti s } \\
\text { količinskega vidika }\end{array}$ & $4,6 \pm 0,94 \quad U=184,5 ; p=0,013$ \\
$\begin{array}{l}\text { Znam načrtovati program gibalnih/športnih aktivnosti z } \\
\text { organizacijskega vidika }\end{array}$ & $4,6 \pm 0,96 \quad U=187,5 ; p=0,016$ \\
$\begin{array}{l}\text { Znam prepoznati gibalno nadarjene otroke ter } \\
\text { prilagajati delo njihovim posebnostim }\end{array}$ & $4,6 \pm 0,98$ & \\
$\begin{array}{l}\text { Znam prepoznati otroke s posebnostmi v gibalnem } \\
\text { razvoju in prilagajati delo njihovim posebnostim }\end{array}$ & $4,5 \pm 1,04$ & $U=207 ; p=0,048$ \\
$\begin{array}{l}\text { Znam pripraviti letni program gibalnih/športnih } \\
\text { aktivnosti }\end{array}$ & $4,3 \pm 1,01$ & $U=173 ; p=0,010$ \\
\hline
\end{tabular}

Opombe AS - aritmetična sredina, SO - standardni odklon, $p$ - statistično značilna razlika v oceni kompetentnosti med gibalno/športno aktivnimi in neaktivnimi vzgojiteljicami.

kompetenco znanja oblikovanja učne priprave za uro gibalnih/športnih aktivnosti $(A S=5,2)$, najnižje pa kompetenco znanja priprave letnega programa gibalnih/športnih aktivnosti za otroke $(A S=4,3)$.

Skupina gibalno/športno aktivnih vzgojiteljic statistično značilno višje ocenjuje naslednje kompetence izvajanja gibalnih/športnih aktivnosti z vidika organiziranja (preglednica 3): sposobna sem organizirati izvajanje gibalnih/športnih aktivnosti (G/Š aktivne $5,15 \pm 0,74 ; \mathrm{G} / S$ s neaktivne 4,44 $\pm 0,98$; $U=183 ; p=0,011)$, znam organizirati didaktične gibalne igre $(\mathrm{G} / \zeta$ aktivne $5,15 \pm 0,61 ; \mathrm{G} / S$ neaktivne $4,61 \pm 0,98 ; U=212 ; p=0,040$ ), znam organizirati gibalne/športne aktivnosti v naravi (G/Š aktivne $5,3 \pm 0,56 ; G / S ̌$ neaktivne $4,65 \pm 0,86 ; U=168 ; p=0,007)$ ter sposobna sem načrtovati in izvajati gibalne/športne aktivnosti otrok s posebnostmi v gibalnem razvoju (G/Š aktivne 4,29 $\pm 0,91 ; \mathrm{G} / S ̌$ neaktivne 3,67 $\pm 1,0 ; U=205 ; p=0,041$ ).

Vzgojiteljice, ki delajo z otroki v prvem starostnem obdobju, pri izvajanje gibalnih/športnih aktivnosti v vrtcu z vidika organiziranja najvišje ocenjujejo kompetenco znanja organizacije gibalnih/športnih aktivnosti v naravi $(A S=$ $5,1)$, najnižje pa kompetenco načrtovanja in izvajanja gibalnih/športnih aktivnosti otrok s posebnostmi v gibalnem razvoju $(A S=4,1)$.

Skupina gibalno/športno aktivnih vzgojiteljic statistično značilno višje 
Preglednica 3 Ocena kompetentnosti za izvajanje gibalnih/športnih aktivnosti v vrtcu z vidika organiziranja

\begin{tabular}{lrr}
\hline Trditev & AS \pm SO & $p$ \\
\hline Znam organizirati gibalne/športne aktivnosti v naravi & $5,1 \pm 0,74$ & $U=168 ; p=0,007$ \\
Znam organizirati didaktične gibalne/športne igre & $5,0 \pm 0,79$ & $U=212 ; p=0,040$ \\
Sposobna sem organizirati sodelovanje s starši & $5,0 \pm 0,84$ & \\
$\begin{array}{l}\text { Sposobna sem organizirati sodelovanje s svojim } \\
\text { delovnim okoljem }\end{array}$ & $5,0 \pm 0,78$ & \\
$\begin{array}{l}\text { Sposobna sem organizirati izvajanje gibalnih/športnih } \\
\text { aktivnosti }\end{array}$ & $4,9 \pm 0,89$ & $U=183 ; p=0,011$ \\
$\begin{array}{l}\text { Znam izbrati primernost gibalnih nalog glede na } \\
\text { materialne pogoje dela }\end{array}$ & $4,9 \pm 0,85$ & \\
$\begin{array}{l}\text { Znam izbrati zahtevnost gibalnih nalog, ki so primerne } \\
\text { otrokovemu individualnemu razvoju }\end{array}$ & $4,8 \pm 0,87$ & \\
$\begin{array}{l}\text { Sposobna sem organizirati sodelovanje z zunanjim } \\
\text { okoljem }\end{array}$ & $4,6 \pm 0,95$ & \\
$\begin{array}{l}\text { Sposobna sem načrtovati in izvajati gibalne/športne } \\
\text { aktivnosti otrok s posebnostmi v gibalnem razvoju }\end{array}$ & $4,1 \pm 0,99$ & $U=205 ; p=0,041$ \\
\hline
\end{tabular}

Opombe AS - aritmetična sredina, SO - standardni odklon, $p$ - statistično značilna razlika $v$ oceni kompetentnosti med gibalno/športno aktivnimi in neaktivnimi vzgojiteljicami.

Preglednica 4 Ocena kompetentnosti za izvajanje gibalnih/športnih aktivnosti v vrtcu z vidika izvajanja

\begin{tabular}{lrr}
\hline Trditev & AS \pm SO & $p$ \\
\hline Sposobna sem zagotoviti varnost otrok & $5,2 \pm 0,78$ & $5,2 \pm 0,69$ \\
Znam spodbujati otrokov napredek & $5,2 \pm 0,71$ & \\
Zmorem vzpostaviti varno, prijetno in zaupljivo vzdušje & $5,0 \pm 0,79 \quad$ U $=208 ; p=0,041$ \\
Sposobna sem ustvariti dobro sodelovalno ozračje & $5,0 \pm 0,79$ & \\
Znam motivirati otroka s primernimi učnimi športnimi & & \\
pripomočki & $5,0 \pm 0,91$ & \\
Zmorem izvesti gibalne/športne aktivnosti, ki razvijajo & & \\
gibalne sposobnosti otroka & $4,8 \pm 0,80$ & \\
Znam prenesti v prakso teoretična didaktična znanja & $4,8 \pm 0,90$ & \\
Obvladam demonstracijo gibalnih/športnih aktivnosti & $4,8 \pm 0,78$ & \\
Znam poskrbeti za obvladovanje zmage in poraza pri & & \\
otrocih & $4,7 \pm 0,89$ & \\
Znam uporabljati inovativne učno-vzgojne pristope & &
\end{tabular}

Opombe AS - aritmetična sredina, SO - standardni odklon, $p$ - statistično značilna razlika v oceni kompetentnosti med gibalno/športno aktivnimi in neaktivnimi vzgojiteljicami.

ocenjuje naslednjo kompetenco izvajanja gibalnih/športnih aktivnosti z vidika izvajanja: sposobna sem ustvariti dobro sodelovalno ozračje (G/Š ak- 
Preglednica 5 Ocena kompetentnosti za izvajanje gibalnih/športnih aktivnosti v vrtcu z vidika vrednotenja

\begin{tabular}{lrr}
\hline Trditev & AS \pm SO & $p$ \\
\hline Znam prepoznati otrokov gibalni napredek & $4,9 \pm 0,75$ & $U=214 ; p=0,042$ \\
Znam ustrezno nagraditi otrokov gibalni napredek & $4,7 \pm 0,89$ & $U=191 ; p=0,018$ \\
Zmorem samokritično oceniti svoje delo & $4,7 \pm 0,87$ & \\
Usposobljena sem za izmeritev otrokovega gibalnega & $4,0 \pm 1,18$ & $U=207,5 ; p=0,050$ \\
napredka & & \\
\hline
\end{tabular}

Opombe AS - aritmetična sredina, SO - standardni odklon, $p$ - statistično značilna razlika v oceni kompetentnosti med gibalno/športno aktivnimi in neaktivnimi vzgojiteljicami.

tivne $5,18 \pm 0,72 ; \mathrm{G} /$ Š neaktivne $4,67 \pm 0,84 ; U=208 ; p=0,041)$. Vzgojiteljice, ki delajo $z$ otroki v prvem starostnem obdobju, pri izvajanju gibalnih/športnih aktivnosti $v$ vrtcu $z$ vidika izvajanja najvišje ocenjujejo kompetenco zagotavljanja varnosti otrok $(A S=5,2)$, najnižje pa kompetenco uporabe inovativnih učno-vzgojnih pristopov $(A S=4,7)$.

Skupina gibalno/športno aktivnih vzgojiteljic statistično značilno višje ocenjuje naslednje kompetence izvajanja gibalnih/športnih aktivnosti z vidika vrednotenja: znam prepoznati otrokov gibalni napredek ( $G / S ̌$ aktivne $5,06 \pm 0,65 ; \mathrm{G} / S ̌$ neaktivne 4,61 $\pm 0,85 ; U=214 ; p=0,042)$, usposobljena sem za izmeritev otrokovega gibalnega napredka (G/Š aktivne 4,26 $\pm 1,1 ; \mathrm{G} / \mathrm{S}$ neaktivne 3,56 $\pm 1,19 ; U=207,5 ; p=0,050$ ) in znam ustrezno nagraditi otrokov gibalni napredek (G/Š aktivne 4,94 $\pm 0,74 ; \mathrm{G} / S \breve{~ n e a k t i v n e ~ 4,28 ~} \pm 1,09 ; U=191$; $p=0,018)$. Vzgojiteljice, ki delajo z otroki v prvem starostnem obdobju, pri izvajanju gibalnih/športnih aktivnosti v vrtcu z vidika vrednotenja najvišje ocenjujejo kompetenco prepoznavanja otrokovega gibalnega napredka (AS $=4,9$ ), najnižje pa kompetenco merjenja otrokovega gibalnega napredka ( $A S$ $=4,0$ ), kar je bilo pričakovano glede na zahtevnost vrednotenja gibalnega razvoja otrok v tej starosti (Volmut, Dolenc in Šimunič 2010, 25-26).

Redna gibalna/športna aktivnost pomembno vpliva na telesno, duševno in socialno zdravje. A. Prašnikar $(2011,30)$ v svoji raziskavi ugotavlja, da je skladno s priporočili Svetovne zdravstvene organizacije (2010) dovolj gibalno/športno aktivnih le $37,5 \%$ vzgojiteljic. Tiste vzgojiteljice, ki imajo pozitivnejši odnos do gibalnih/športnih aktivnosti, vanje pogosteje vključujejo tudi otroke, s katerimi delajo v vrtcu (Zajec 2009). Vzgojiteljice prenašajo svoj odnos do gibanja na otroke in s tem, ko so premalo gibalno/športno aktivne, še posebej, če se tega ne zavedajo, to razvado prenašajo tudi na mlajše generacije. Poklic vzgojitelja je eden od poklicev, ki zahteva strokovnost na vseh področjih otrokovega razvoja, spretnost dobrega opazovanja, odgovornost, 
dobro psihofizično pripravljenost ter razvitost gibalnih in ročnih spretnosti. Uspešnost v vzgojiteljskem poklicu je odvisna tudi od dobre telesne pripravljenosti, saj se vzgojitelji vsakodnevno srečujejo s številnimi obremenitvami (Gregorc idr. 2010). M. Jeram $(2016,26)$ poroča, da vzgojiteljice, ki se s športom ukvarjajo več kot dvakrat tedensko, bolje komunicirajo $z$ otroki na področju gibanja kot tiste, ki se s športom ukvarjajo enkrat tedensko ali se z njim sploh ne ukvarjajo. M. Sajevic (2016) je v svoji raziskavi ugotovila, da se na splošno vzgojitelji sicer zavedajo pomena in pomembnosti gibalnih/športnih aktivnosti za otrokov celostni razvoj; navade in vzorci gibalnih/športnih aktivnosti, pridobljeni v obdobju otroštva in mladostništva, se namreč $v$ veliki večini ohranijo tudi v kasnejših obdobjih življenja.

\section{Sklep}

Vzgojiteljeva primarna naloga je oblikovati pogoje in možnosti, da se bo otrok lahko celostno razvijal. Gibalna/športna aktivnost ima za celosten razvoj otroka izreden pomen. Glede na to, da predšolski otroci v veliki večini med tednom v programih predšolske vzgoje preživijo pretežni del dneva, je pomembno, $v$ kakšne aktivnosti so vključeni, predvsem pa tudi, na kakšen način so te načrtovane, organizirane, izvajane in vrednotene. Rezultati raziskave so pokazali, da vzgojitelji svojo kompetentnost za razvoj področja gibanja otrok v primerjavi z ostalimi področji na splošno ocenjujejo kot dobro. $Z$ različnih vidikov vodenja gibalnih/športnih aktivnosti pa se je izkazalo, da v kompetencah za izvajanje gibalnih/športnih aktivnosti med gibalno/športno aktivnimi in neaktivnimi vzgojiteljicami ni bistvenih razlik. So pa te opazne na ostalih področjih kompetentnosti, torej pri načrtovanju, organiziranju in vrednotenju gibalnih/športnih aktivnosti otrok. Iz tega lahko sklepamo, da vzgojiteljice, ki se redno, tudi v svojem prostem času, ukvarjajo $z$ gibalno/športno aktivnostjo, te vzorce in znanja prenašajo na otroke v skupini, s katero delajo. Rezultati, ki smo jih pridobili v okviru predstavljene študije, predstavljajo prikaz pomena tematike gibalno/športno aktivnih in neaktivnih vzgojiteljic, ki podajajo oceno svoje kompetentnosti za razvoj področja gibanja pri predšolskih otrocih prvega starostnega obdobja. Z rezultati lahko prikažemo pomen skrbi vzgojiteljic predšolskih otrok za lastno gibalno aktivnost in zdravje, saj posledično izražajo tudi večjo kompetentnost za razvoj področja gibanja otrok, ki so jim zaupani. Prav gotovo bi bilo v prihodnosti smiselno tudi objektivno, $z$ uporabo primerne merilne opreme, preveriti povezavo med gibalno/športno aktivnostjo vzgojiteljic in njihovo kompetentnostjo za razvoj področja gibanja otrok, pri tem pa upoštevati tudi velikost vzorca preiskovancev. Izredno zanimiva pa bi bila tudi zahtevnejša študija, 
kjer bi objektivno preverjali gibalno/športno aktivnost vzgojiteljic in gibalno kompetentnost otrok, vključenih v njihove skupine.

Literatura

Gallahue, D. L., J. C. Ozmun in J. Goodway. 2012. Understanding Motor Development: Infants, Children, Adolescents, Adults. New York: McGraw-Hill.

Gregorc, J., J. Štihec, M. Videmšek, A. Cemič in M. Meško. 2012. »The Quality of Kindergarten Care As an Important Element of the Subjective Theories." Acta Universitatis Palackianae Olomucensis: Gymnica 42 (1): 17-25.

Jeram, M. 2016. »Inovativni pristopi poučevanja gibalnih/športnih aktivnosti v zgodnjem otroštvu. "Diplomska naloga, Univerza na Primorskem.

Kohont, A. 2005. »Kompetenčni profili slovenskih strokovnjakov za upravljanje človeških virov." Magistrsko delo, Univerza v Ljubljani.

Lemos, A. G., E. L. Avigo in J. A. Barela. 2012. »Physical Education in Kindergarten Promotes Fundamental Motor Skill Development.« Advances in Physical Education 2 (1): 17-21.

Malina, R., C. Bouchard in O. Bar-Or. 2004. Growth, Maturation, and Physical Activity. Champaign, IL: Human Kinetics.

Maretič Požarnik, B. 2012. Psihologija učenja in pouka. Ljubljana: DZS.

Ministrstvo za šolstvo in šport. 1999. Kurikulum za vrtce: predšolska vzgoja v vrtcih. Ljubljana: Ministrstvo za šolstvo in šport.

Organisation for Economic Co-Operation and Development. 2013. Innovative Learning Environments. Pariz: Organisation for Economic Co-Operation and Development.

Pišot, R., in G. Jelovčan. 2012. Vsebine gibalne/športne vzgoje v predšolskem obdobju. Koper: Annales.

Plevnik, M., in R. Pišot, ur. 2016. Razvoj elementarnih gibalnih vzorcev v zgodnjem otroštvu. Koper: Annales.

Prašnikar, A. 2011. »Povezanost gibalnih/športnih aktivnosti vzgojiteljic v povezavi z izbranimi dejavniki zdravega načina življenja.« Diplomska naloga, Univerza v Ljubljani.

Retar, I., in J. Lepičnik-Vodopivec. 2017. »Kompetentnost vzgojiteljev za inovativno gibalno poučevanje.« Pedagoška obzorja: časopis za didaktiko in metodiko 32(1): 17-32.

Retar, I., M. Plevnik in E. Kolar. 2013. »Key Competences of Slovenian Sport Managers."Annales kinesiologiae 4 (2): 81-94.

Sajevic, M. 2016. „Zavedanje vzgojiteljev o pomenu gibalnih/športnih aktivnosti za otrokov celostni razvoj.« Diplomska naloga, Univerza na Primorskem.

Timmons, B. W., P. J. Naylor in K. A. Pfeiffer. 2007. »Physical Activity for Preschool Children: How Much and How?« Applied Physiology, Nutrition, and Metabolism 32 (S2E): S122-S134. 
UNESCO. 2011. International Standard Classification of Education ISCED 2011. Quebec: UNESCO.

Videmšek, M., in R. Pišot. 2007. Šport za najmlajše. Ljubljana: Fakulteta za šport. Volmut, T., P. Dolenc in B. Šimunič. 2010. »Metode spremljanja in merjenja gibalne/športne aktivnosti otrok.«V Otroci potrebujemo gibanje, ur. B. Šimunič, T. Volmut in R. Pišot, 25-32. Koper: Annales.

Weiler, R., S. Allardyce, G. P. Whyte in E. Stamatakis. 2013. »ls the Lack of Physical Activity Strategy for Children Complicit Mass Child Neglect?« British Journal of Sports Medicine 48 (13): 1010-1013.

World Health Organization. 2010. Global Recommendations on Physical Activity for Health. Geneva: World Health Organization.

Zajec, J. 2009. »Povezanost športne dejavnosti predšolskih otrok in njihovih staršev z izbranimi dejavniki zdravega načina življenja.« Doktorska disertacija, Univerza v Ljubljani.

\section{Physical (In)activity of Preschool Teachers and Their Competence for Development of Movement among First Age Group of Preschool Children}

The need for movement is a child's primary need. Therefore, the development of the movement, as one of the fields of activity in preschool, has a special importance. In the early childhood, the child is extremely perceptible for the impulses of the environment, and the influence of the acquired experiential experiences in this period is of great importance for his further development. Kindergarten is, in addition to parents, an extremely important environment during childhood, as children spend most of their day in it. Children should adopt many motor skills in the environment of the kindergarten, which is connected with the appropriate planning, organization, implementation and evaluation of the physical activities guided by the preschool teacher, which is also influenced by its competence. Sixty-five preschool teachers, who work with first age group of preschool children, cooperated in the study. We were interested in the development of their competences for developing the content of the movement and physical activity also in connection with their own level of physical activity. We found that more physical active teachers assess their competences for the development of pre-school children's movements higher.

Keywords: development, physical activity, competency, environment, child 